\title{
Survey Analysis for Quality Enhancement of MSRTC Bus Station - A Review Research
}

\author{
Prof. Sunil R. Kewate ${ }^{* 1}$, Prof. Vivek R. Gandhewar*2, Miss.Vaishnavi R. Holey*3 \\ ${ }^{1}$ Research Schalor \& Assistant Professor, Mechanical Engineering, Department Govt. College of Engineering, Amravati, \\ Maharashtra, India, \\ ${ }^{2}$ Associate Professor, Mechanical Engineering, Department, Jawaharlal Darda Inst, of Engg.\& Tech. Yavatmal , \\ Maharashtra, India \\ ${ }^{3}$ M.Tech. Student, Mechanical Engineering, Department Govt. College of Engineering, Amravati, Maharashtra, India.
}

\section{Article Info}

Volume 8, Issue 5

Page Number : 362-369

\section{Publication Issue}

September-October-2021

\section{Article History}

Accepted : 08 Oct 2021

Published : 16 Oct 2021

\section{ABSTRACT}

A Survey analysis is conducted by quality function deployment (QFD) at bus station in Amravati, INDIA to know and identify existing the demands and request of the users and to improve the quality of the service provide by MSRTC bus station in Amravati. To identify the needs of the customers the survey has been conducted by using the defined questionnaire and it was distributed to 5000 users. The responses of these surveys have been used as a feedback in the first stage of QFD. Total 20 main features and 17 sub features have been designed by considering all the aspects of public transport system. In this present study, the output of the surveys indicated that, in order to improve the quality of the public transport service, in this paper, the main focus has been given on the ticket prices and frequency of the transport system. Keywords : MSRTC, Survey, transport service, facilities, QFD

\section{INTRODUCTION}

Maharashtra State Road Transport Corporation (MSRTC) is state owned corporation which provides transport services to the remote or unreached rural areas in Maharashtra; but still it is known as provider of poor quality service and it is not meeting the expectations of the passengers. There are number of private transport services which are providing comfortable services to the passengers; and therefore most of the passengers are attracted towards these private transport services. Though they are putting good services and saying good services and facilities given by MSRTC But in order to maintain and monitor the facilities at each bus station and also to maintain the quality in facilities available at each bus stations are the continues assessment activity. It should be followed by using continues feedback of passengers in the form of responses to monitor the quality of service provided at each bus station. In this paper, it tried to examine the quality of services and facilities available at MSRTC bus station in Amravati by translating the Voice of the Customer (VoC) into new services that truly satisfy their needs. In this 
paper survey analysis is taken by on the basis of information collected from passengers through questionnaires, interviews and observation done at bus stations related with the services and facilities provided by MSRTC and also by taking direct opinions of passengers regarding services provided by Maharashtra State Road Transport Corporation.

In this present study, the research survey design is structured by the QFD method process that helps to understand the importance that customers attach to their various expectations and used for translating customer requirements into functional design and then utilizing a progression of matrices to link operational processes and decisions to customer needs.

\section{LITERATURE REVIEW}

An extensive literature survey of Quality enhancement of services has been covered in this study. Various tools are used by researchers for enhancement of quality of service- Dr. Arvind Chaudhari present an attempt is made to study the real position of facilities provided at Bus Stations for comfort of passengers and understand the level of satisfaction of passengers from the services provided by it. Dr. Prakash Vishnu Pise examines the public and private transportation services in terms of passenger's satisfaction and find out the reasons of passenger dissatisfaction in case of MSRTC on the basis of the state of satisfaction depends on number of psychological and physical variables. Madhuri Rahatgaonkar and Mayura Mathankar both tried to attempt the satisfaction level of passengers on the services provided by Maharashtra State Road Transport Corporation and also awareness of passengers about its services. Pakdil et al. [22] established a QFD methodology that conglomerates the traveller's opinions and transport service provider's practical information to expand quality of the road passenger transport services. Authors found that the most essential aspects in satisfying customer voice are, employee's concerned approach toward consumer's, technical conditions of buses, error-free facilities' and experienced employees. Drawback of this study was sample size (285 respondents) from just one focus group. This paper presents a case study using QFD method to find urban public transport user's wants and needs and to advance service quality in urban public passenger transport in Belgrade. The paper rumours how QFD could be applied for improving the quality of service in urban public transport.

\section{METHODOLOGY}

This proposed study is based on primary and secondary data for the proper and factual finding and analysis. Primary data is collected from the respondents with the help of the questionnaire and interview of the passengers who are travelling within the district pass-through Amravati bus station. Employees of MSTRC at Bus Station are also interviewed for cross checking the information provided by respondents and also help to come up with useful recommendations. The basic objectives of methodology -

1) To Search user's wants and needs regarding the quality of service

2) Grading of quality features importance for users;

3) Assessing the user's fulfilment level;

4) Relative investigation of changes in userse prospects and satisfaction with the quality of service in public transport vs. individual transport.

In this paper, a descriptive survey research design is taken by the following steps-
a) Research Questionnaire Questions
b) Population and Sample Selection
c) Data Analysis-
d) Interview. 


\section{DATA ANALYSIS AND RESULT}

The main aim of this research paper was to evaluate passengers $^{\text {ee }}$ satisfaction on service quality and Satisfaction on services of MSRTC Bus station at Amravati. The data analysis is carried out and result is explained as follows-

\section{Passenger details}

Table.1 shows the age of the customer, type of travelling, type of bus, and nature of travel.

\begin{tabular}{|c|c|c|c|c|}
\hline Group & Travel & Type of travelling & Type of bus & $\begin{array}{c}\text { Continuous } \\
\text { travel }\end{array}$ \\
\hline I & Below 25 years & Less than $10 \mathrm{Hrs}$. & Non $A / C$ Bus & Contimous \\
\hline II & Between 26 and 40 years & Less than $15 \mathrm{Hrs}$. & Non $A / C$ Bus & Contimuous \\
\hline III & Between 41 and 55 years & Less than $15 \mathrm{His}$. & Non $A / C$ Bus & Contimuous \\
\hline IV & Betreen 56 and 60 years & Less than $15 \mathrm{His}$. & Non $A / C$ Bus & Contimous \\
\hline V & Above 60 years & Less than $10 \mathrm{Hrs}$. & Non $A / C$ Bus & Continuous \\
\hline
\end{tabular}

Table. 2 shows the number of participants in the survey and its bifurcation according to age and gender. There were 2975 female participants while 2075 male participants in the survey.

\begin{tabular}{|c|c|c|}
\hline Sr. & Description & Number of respondent \\
\hline 1 & Number of respondent asked to participate in survey & 5000 \\
\hline 2 & Number of groups categorized while surveging & 7 \\
\hline 3 & Number of male respondents & 2075 \\
\hline 4 & Number of female respondents & 2925 \\
\hline 5 & Number of respondents below age 25 & 850 \\
\hline 6 & Number of respondents between age 26 and 40 & 900 \\
\hline 7 & Number of respondents between age 41 and 55 & 1575 \\
\hline 8 & Number of respondents between age 56 and 60 & 875 \\
\hline 9 & Number of respondents above 60 & 800 \\
\hline
\end{tabular}

Table. 3 shows the percentage of passenger according the gender and age.

\begin{tabular}{|c|c|c|}
\hline & Frequency & Percentage \\
\hline \multicolumn{3}{|c|}{ Gender } \\
\hline Male & 2075 & $41.5 \%$ \\
\hline Female & 2925 & $58.5 \%$ \\
\hline Total & 5000 & $100 \%$ \\
\hline \multicolumn{3}{|c|}{ Age } \\
\hline Number of respondents belav age 25 & 850 & $17 \%$ \\
\hline Number of respondents betreen age 26 and 40 & 900 & $18 \%$ \\
\hline Number of respondents between age 41 and 55 & 1575 & $31.5 \%$ \\
\hline Number of respondents between age 56 and 60 & 875 & $17.5 \%$ \\
\hline Nivmber of respondents above 60 & 800 & $16 \%$ \\
\hline Total & 5000 & $100 \%$ \\
\hline
\end{tabular}

\section{Response of passengers}

According to Table 5.3 above, $41.5 \%$ of the respondents were males while the rest $58.5 \%$ were females. Concerning the age of respondents, below 25 were $17 \%$, 26-40 were $18 \%$, $41-55$ were $31.5 \%$, 56-60 were $17.5 \%$ and respondents above 60 were $16 \%$. From this, it can be seen that almost $66 \%$ of the respondent's age is 55 and below it.

Table 4 shows the responses of passenger on service quality indicators. It has been seen that $60 \%$ of customers are satisfied with the current booking charges with the quality index of 0.6 while $44 \%$ of consumers are unhappy with the cleanliness of the bus station and buses. Remarkable $61 \%$ of the consumers are satisfied with the concession and the frequency of the buses provided by the MSRTC. At the same time $50 \%$ of the customers are unhappy with the canteen facility while $78.5 \%$ of the customers are happy with the advance display system provided by the bus. Most importantly 59\%, 55\% and $60 \%$ of the customers are happy with the behavior of the employee, safety of the kids and women respectively. $78 \%$ of the customers are happy with the facility of messages of timing.Table.4: shows the responses of passengers on service quality indicators. 
Prof. Sunil R. Kewate et al Int J Sci Res Sci \& Technol. September-October-2021, 8 (5): 362-369

\begin{tabular}{|c|c|c|c|c|c|c|c|c|c|c|}
\hline \multicolumn{11}{|c|}{ Respondents } \\
\hline & \multirow[t]{2}{*}{ Items } & \multicolumn{2}{|c|}{ Satisfied } & \multicolumn{2}{|c|}{$\begin{array}{l}\text { Strongly } \\
\text { satisfied }\end{array}$} & \multicolumn{2}{|c|}{ Uns atisfied } & \multicolumn{2}{|c|}{$\begin{array}{l}\text { Strongly } \\
\text { vnsatisfied }\end{array}$} & \multirow[t]{2}{*}{$\begin{array}{l}\text { Quality } \\
\text { Index }\end{array}$} \\
\hline & & Freq. & $\%$ & $\begin{array}{l}\text { Freq. } \\
\end{array}$ & $\%$ & Fraq. & $\%$ & Freq. & $\%$ & \\
\hline 1. & Current charges of booking & 3000 & 60 & - & - & 2000 & 40 & $\cdot$ & - & 0.6 \\
\hline 2. & Time table of bus & 2550 & 51 & - & - & 2450 & 49 & $\cdot$ & - & 0.51 \\
\hline 3. & $\begin{array}{l}\text { Avvalability for reserved } \\
\text { saats }\end{array}$ & 2525 & 50.5 & - & $\cdot$ & 2475 & 49.5 & - & - & 0.50 \\
\hline 4. & Cleanliness of bus stop & 2275 & 45.5 & 525 & 10.5 & 2200 & 44 & - & - & 0.56 \\
\hline 5 & $\begin{array}{l}\text { Concession in pass for daily } \\
\text { travelling }\end{array}$ & 3050 & 61 & - & - & 1950 & 39 & - & - & 0.61 \\
\hline 6 & Paak timing & 3050 & 61 & - & - & 1950 & 39 & - & - & 0.61 \\
\hline 7 & $\begin{array}{l}\text { Opinion about facility } \\
\text { during travelling }\end{array}$ & 2300 & 46 & $\cdot$ & $\cdot$ & 2700 & 54 & - & - & 0.46 \\
\hline 8 & $\begin{array}{l}\text { Treatment for physically } \\
\text { handicap person }\end{array}$ & 2975 & 59.5 & - & $\cdot$ & 2025 & 40.5 & - & - & 0.56 \\
\hline 9 & Interior of bus & 2750 & 55 & 350 & 7 & 1900 & 38 & - & - & 0.62 \\
\hline 10 & $\begin{array}{l}\text { More number of issves } \\
\text { counner }\end{array}$ & 3750 & 75 & $\cdot$ & $\cdot$ & 1250 & 25 & - & - & 0.75 \\
\hline 11 & Canten facility & 2175 & 43.5 & 300 & 6 & 2525 & 50.5 & $\cdot$ & - & 0.5 \\
\hline 12 & $\begin{array}{l}\text { Advance technology display } \\
\text { of routes in bus }\end{array}$ & 3925 & 78.5 & - & - & 1075 & 21.5 & - & - & 0.78 \\
\hline 13 & $\begin{array}{l}\text { Beharior of bus employee } \\
\text { with passenger }\end{array}$ & 2950 & 59 & 325 & 6.5 & 1725 & 34.5 & - & - & 0.65 \\
\hline 14 & $\begin{array}{l}\text { Quality seats, ventilation \& } \\
\text { luggg age p pacement facility }\end{array}$ & 2775 & 55.5 & 175 & 3.5 & 2050 & 41 & $\cdot$ & - & 0.6 \\
\hline 15 & Women?'s safery & 3000 & 60 & - & . & 2000 & 40 & - & - & 0.6 \\
\hline 16 & Childrents safety & 2775 & 55.5 & - & $\cdot$ & 2225 & 44.5 & $\cdot$ & - & 0.55 \\
\hline 17 & $\begin{array}{l}\text { Reservation facility in bus } \\
\text { like rallway faclity }\end{array}$ & 3125 & 62.5 & - & $\cdot$ & 1875 & 37.5 & $\cdot$ & - & 0.63 \\
\hline 18 & Pollution level due tobuses & 1525 & 30.5 & 1750 & 35 & 1725 & 34.5 & - & - & 0.66 \\
\hline 19 & $\begin{array}{l}\text { Facility of messages of } \\
\text { timing to bus to daily } \\
\text { passengers }\end{array}$ & 3900 & 78 & - & - & 1100 & 22 & - & - & 0.78 \\
\hline 20 & $\begin{array}{l}\text { Eligiblep passenger get } \\
\text { proper facility of reerved seats }\end{array}$ & 3200 & 64 & - & - & 1800 & 36 & - & - & 0.64 \\
\hline
\end{tabular}

\section{Passenger satisfaction}

Table.5 shows the responses of the passengers on service satisfaction. It can be concluded from the responses given by the consumers that most of the consumers are happy with the service provided by the MSRTC. It has been observed that around $80 \%$ of the customers are happy with the service provided by MSRTC. $68 \%$ of the consumers believe that the travel with MSRTC is always a better option than the other services. More importantly $64 \%$ of the consumers responded that the MSRTC is good option for all age consumers while $32 \%$ customers were not happy with the MSRTC services. In addition to that $76 \%$ of the consumers were ready to recommend the MSRTC to the people to travel over other options.
Table 5 : Responses of passengers on service satisfaction

\begin{tabular}{|c|c|c|c|c|c|c|c|c|c|}
\hline & Items & $\begin{array}{l}\text { Agee } \\
\text { Freq. \% }\end{array}$ & $\begin{array}{l}\text { Strongly } \\
\text { agree } \\
\text { Freq. \% }\end{array}$ & $\begin{array}{l}\text { Disagree } \\
\text { Freq. \% }\end{array}$ & $\mid \begin{array}{l}\text { Stron } \\
\text { disag } \\
\text { Freq }\end{array}$ & $\%$ & $\left|\begin{array}{l}\text { No } \\
\text { comm } \\
\text { Freq }\end{array}\right|$ & $\%$ & $\begin{array}{c}\text { Satisaction } \\
\text { index }\end{array}$ \\
\hline 1 & $\begin{array}{l}\text { Are you satified with MSRTC } \\
\text { Amravat? }\end{array}$ & $2200 \quad 44$ & $1800^{36}$ & $800 \quad 16$ & $6 \quad 200$ & 4 & . & - & 3.6 \\
\hline 2 & $\begin{array}{l}\text { Travel withMSRTC is always } \\
\text { better travelling option? }\end{array}$ & $1600 \quad 32$ & $1800 \quad 36$ & $800 \quad 16$ & $6 \quad 600$ & 12 & 200 & 4 & 3.8 \\
\hline 3 & $\begin{array}{l}\text { Do you thint that travel with } \\
\text { MSRTC is goodfor all age } \\
\text { group? }\end{array}$ & $800 \quad 16$ & $2400 \quad 48$ & 120024 & 4600 & 12 & . & . & 4.8 \\
\hline 4 & $\begin{array}{l}\text { Recommendation of travel with } \\
\text { MSRTC to people is the good } \\
\text { suggestion? }\end{array}$ & $1800 \quad 36$ & $2000 \quad 40$ & 4008 & 400 & 8 & 400 & 8 & 4.3 \\
\hline
\end{tabular}

\section{Application of QFD method process at MSRTC Bus} station-

The process of determining the service quality at MSRTC bus station in Amravati comprised nine interconnected steps through which, based on userse requests, final solutions related to structure and quality of transport service were defined.

\section{Step 1: Users' Request Identification.}

The gender structure has shown that a greater number of females (58.5\%) used MSRTC transport than males (41.5\%). It is interesting to note that $66 \%$ of customers are below 55.User's requests are the basic item data of QFD process and thus the heart for quality matrix set up. Understanding exactly what customers expect is the most crucial step in outlining and conveying high-quality service [39]. In this research, an overall set of twenty features and a total of 17 sub-features were used, which describe all aspects of quality of system and services in urban public passenger transport (Table 1).

\section{Step 2: Defining Importance of Users' Requests.}

For a particular quality sub-features, customers were providing answers with respect to its importance ranking. Based on these userse statements an importance ranking was calculated for every feature. Table.6 presents customer requirement and important rating. 


\section{Step 3: Comparison with Competition.}

The aim of this step is to deliver superior quality of service with respect to competition with which comparison was conducted. For relative analysis, travel service and cab service was selected. Comparison with competitive transport mode from users" point of view was shown through benchmarking method. A five-grade scale (from 1insufficient to 5-excellent) is used for comparison. The study shows that request ticket price, frequency, age relaxation and staff training was ranked worse with cab services compared to MSRTC system. Vehicle comfort in MSRTC public transport was particularly badly graded which not a surprise is bearing on mind an issue of collectively related to public transport. The other reason can be found in relatively old vehicle fleet. The safety for the women and the kids, and emergency contact facility was ranked worse in case of travel services when compared with MSRTC services. It is interesting that these data are in line with all previous researches of estimated quality of service, which showed that vehicle comfort is a quality service feature where passengers in urban public passenger transport are the least satisfied [40].

\begin{tabular}{|c|c|c|c|c|c|c|c|c|c|c|c|c|c|c|c|}
\hline Our Sevice $\Delta$ & 4 & $\Delta \mathrm{A}$ & & $\Delta$ & $A$ & & & & & $\Delta$ & & & & $\Delta$ & 5 \\
\hline Travel Service — & & (a) & 4 & 마 & & $\triangle \Delta$ & & 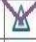 & & & 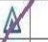 & & 4 & $\Delta$ & 4 \\
\hline Cab Sevice $\Delta$ & (] & $\mathbb{Q}$ & 國 & & & 可 [ & & ] & & & 何 & & & & 3 \\
\hline & $\Delta$ & & $\Delta$ & $\varnothing$ & (1) & & [ & $\Delta$ & ( & Y & $\Delta[$ & & $\Delta$ & 可 & 2 \\
\hline & & $\Delta$ & & & $\Delta$ & 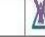 & $\Delta$ & & $\Delta$ & & $\angle$ & $\Delta[$ & 0 & & 1 \\
\hline
\end{tabular}

Figure.1: Comparison with competitors

\section{Step 4: Service Features Definition.}

The subsequent step in procedure is describing service features, which affect fulfillment of each provided request. From the wide range of transport offer elements and other elements of provided transport service, so-called system Key Performance Indicators (KPI), i.e. features, which qualitatively describe users requests were selected [41]. The significance of tariff policy and pricing policy was revealed through three parameters (tickets price, tariff policy, concession in passes) in the system. Next selected features refer to dynamic features of transport network (headway, frequency) and features of the basic resource- vehicle (technical regularity, interior of bus, vehicle repairing). The next features were selected as (pass issue counter, pollution level, user information level, safety environment, cleanliness, canteen facility). Last features refer to staff (staff training) in the system. Every feature fits into clearly defined functional request, which is formed based on userse requests. With the improvement of these features, better service, better performance are achieved and functional requests are fulfilled and thus user gets what he wants as well (expected quality of service).

\section{Step 5: Correlations of Users' Requests and Service} Features.

Through the main matrix of house of quality, correlation between users" requests and elements of the service design were set. The relation intensity was shown with different symbols, atomicity 1-3-9 (grade 1 stands for weak connection, grade 3 middle and grade 9 strong connections). In literature, models of interdependence of all mentioned indicators were developed which were taken as the basis in correlation intensity defining. One service features can influence more users" request with different correlation intensity just as one user request can be influenced by a number of service features as shown in figure.2.

The analysis showed that current charges and ticket price have high correlation; time table of bus to frequency, cleanliness of bus stop and cleaning sweeper, concession in pass and age relaxation, pass issue counter and staff to issue pass, employee behaviour and staff, quality of seats ventilation and vehicle interior, pollution level and safety environment, message facility and user information. Table 2 provides an overall matrix of interdependence of user's requests and service features. 


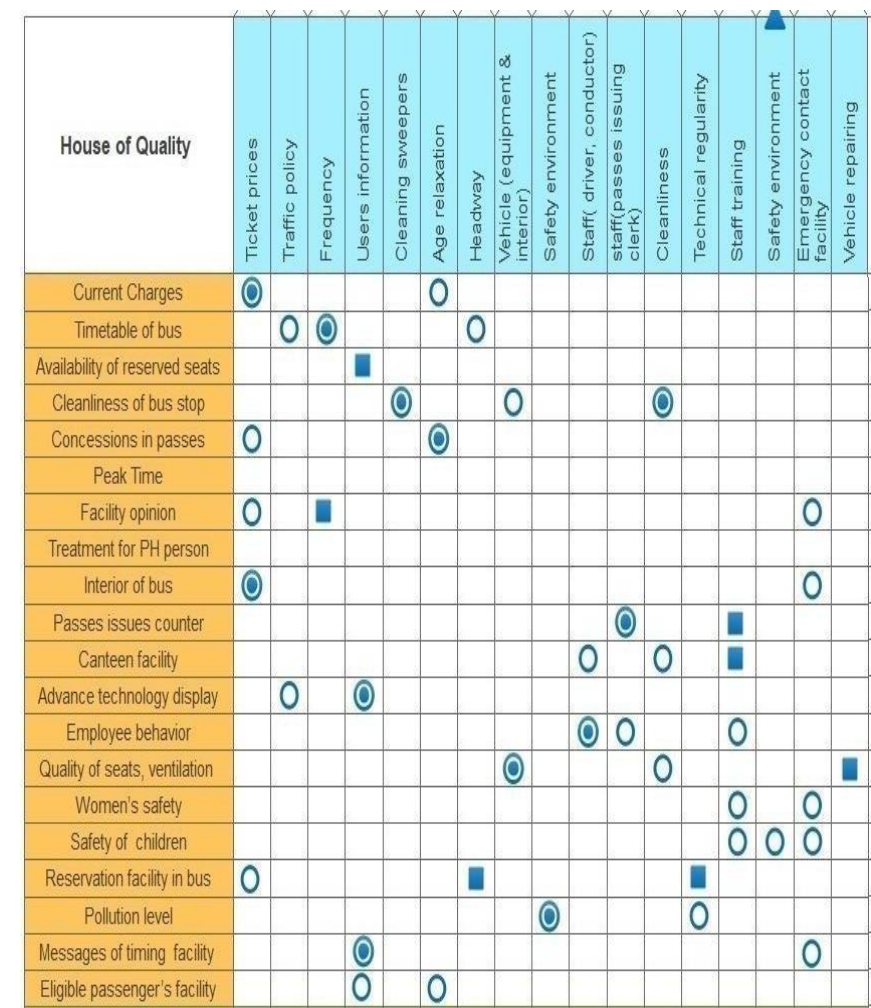

Figure 2: Correlations of Users"e Requests and Service Features

\section{Step 6: Correlations between Service Features.}

Within the house roof there is a matrix, which points out at potential conflict objectives between two features. Interdependence was shown with suitable symbols and the correlation itself can be strong positive, positive, no relation. Previous researches on the interdependence between transport services features were used in this analysis as well. It was shown that ticket price and age relaxation, frequency and headway, cleanliness and cleaning sweeper, vehicle interior and vehicle repairing have strong degree of correlation, i.e. these two features depend on each other as shown in figure 3.

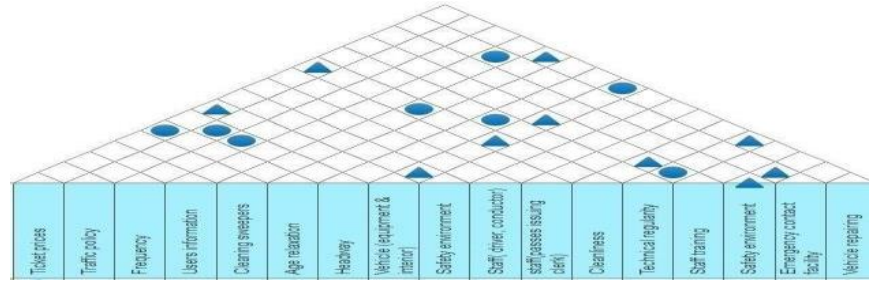

Figure 3: Correlations between Service Features.

\section{Step 7: Quality Plan.}

This step defines quality plan, which also comprises criteria of users" importance, which is used in strategic management of public passenger transport system. The plan comprises: criteria of users importance; target value for development of system image at the market, though grading on the scale from 1 to 5 , where 1 stands for changes, 3 for development, 5 for service better than competitor's; sale factor, assigning 1 if a service has negative sale effect and 2 if service has positive sale effect. Table 6 shows the customer important rating.

Table 6: Customer important rating (Voice of Customer Deployment)

\begin{tabular}{|cll}
\hline Sr. No. & \multicolumn{1}{c}{ Customer requirement } & $\begin{array}{c}\text { Customer } \\
\text { Importance rating }\end{array}$ \\
1 & Current Charges & 5 \\
\hline 2 & Timetable of bus & 5 \\
\hline 3 & Availability of reserved seats & 3 \\
\hline 4 & Cleanliness of bus stop & 4 \\
\hline 5 & Concessions in passes & 2 \\
\hline 6 & Peak Time & 4 \\
\hline 7 & Facility opinion & 2 \\
\hline 8 & Treatment for PH person & 2 \\
\hline 9 & Interior of bus & 2 \\
\hline 10 & Passes issues counter & 2 \\
\hline 11 & Canteenf acility & 3 \\
\hline 12 & Advance technology display of routes & 3 \\
\hline 13 & Employee behavior with passenger & 4 \\
\hline 14 & Quality of seats, ventilation and luggage?s facility & 4 \\
\hline 15 & Women?s safety & 4 \\
\hline 16 & Safety of children & 3 \\
\hline 17 & Reservation facility in bus like railway facility & 3 \\
\hline 18 & Pollution level & 2 \\
\hline 19 & Messages of timing facility & 3 \\
\hline 20 & Eligible passenger's facility for reserved seats & 2 \\
\hline & & 3 \\
\hline
\end{tabular}

\section{Step 8: Service features analysis.}

In the pre-final step based on the analysis of the collected results, absolute importance of some features was defined, generated as an arithmetic sum of all products of users"e importance and correlation degree of every service feature, in line with the following formula:

Absolute $=$ Costumer importance ranking $\mathrm{X}$ relationship rating Relative $=$ Summation of absolute/ value of individual absolute value

The analysis showed that for MSRTCE service at Amravati, system operating parameters have the 
greatest effect (reliability): ticket price with relative importance $13 \%$; user information with relative importance 9.7\%; frequency with relative importance $9.1 \%$. These are followed by the cleanliness with relative importance $8.3 \%$, vehicle interior with $7.0 \%$ and age relaxation with $6.0 \%$ as shown in figure 4.

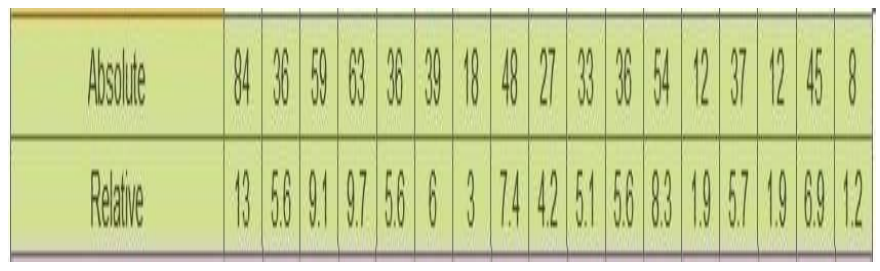

Figure 4: Service feature analysis

\section{Step 9: Service Features Importance Ranking.}

Based on absolute and relative importance, every service feature got its importance ranking. Within this step, importance of implementation of some service features were ranked through assigning value 1 for the most important solution and 10 for the least important solution. Ranking of features in line with importance is followed also by their absolute and relative importance so the greatest importance should be assigned to ticket price - rank 1, user information - rank 2; frequency - rank 3 . Cleanliness, emergency contact facility, staff training is ranked at positions 4,5 and 6 , respectively. Focusing on these key features, quality of service can be developed and users ${ }^{\text {ee }}$ satisfaction level can increase. These features represent a step into the QFD method second stage.

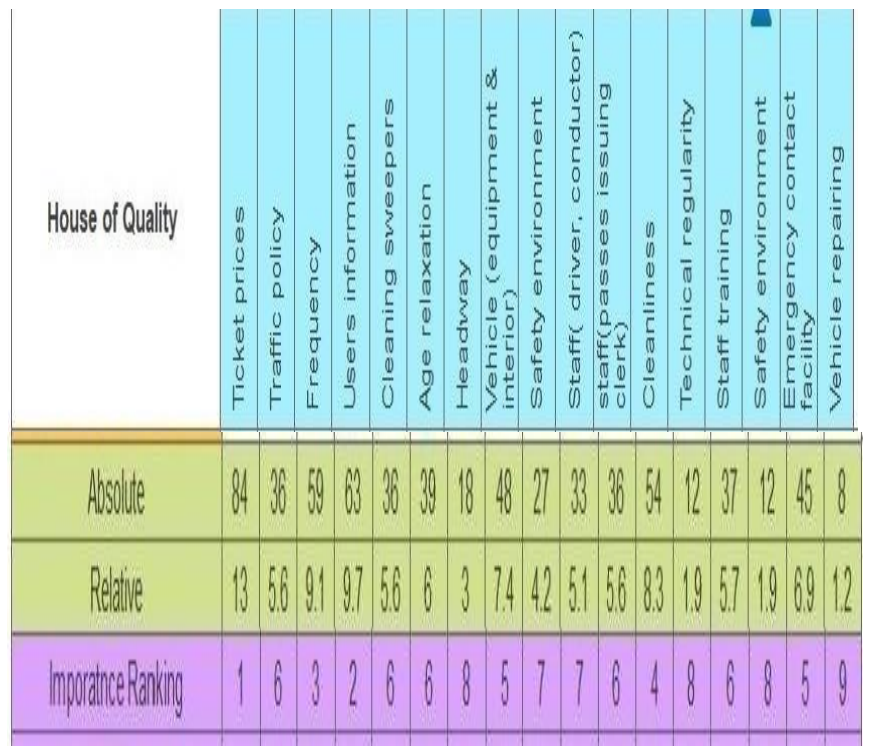

Figure 5: Importance ranking

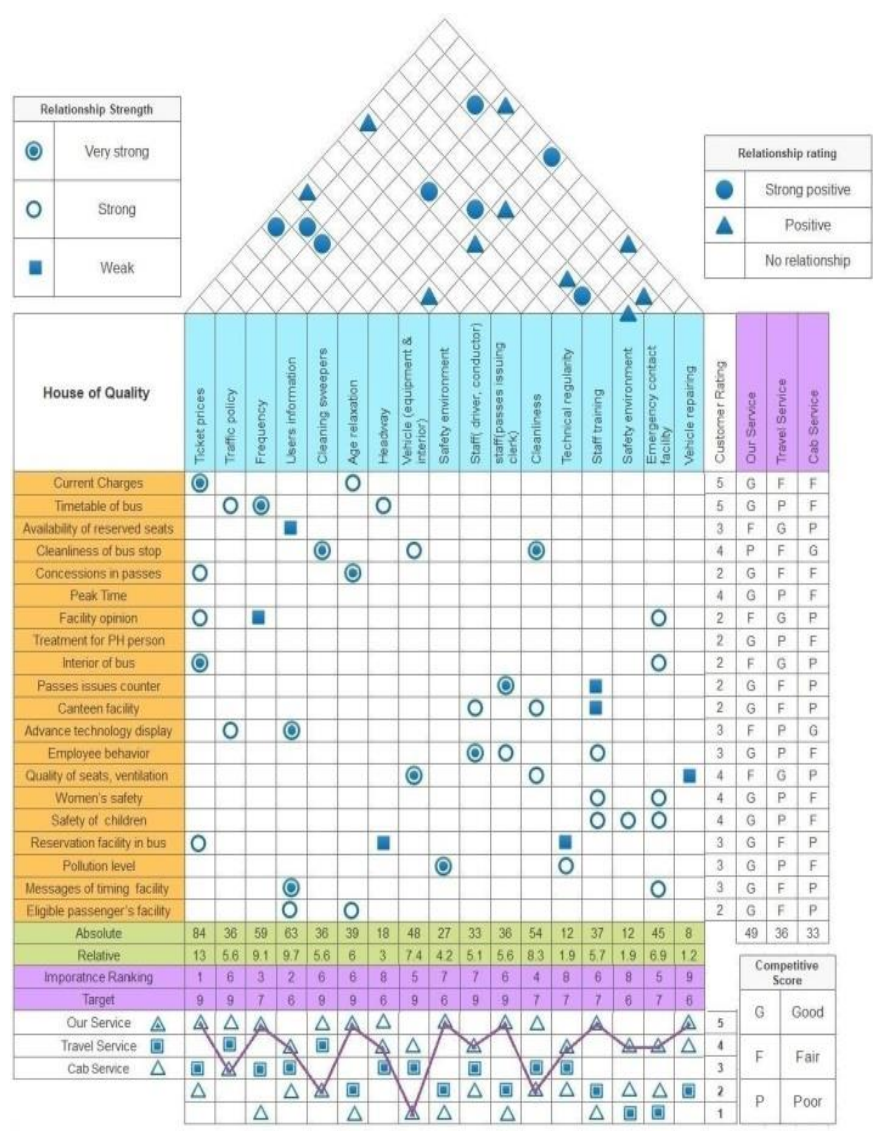

Figure 6: House of Quality developed in relation with quality of service at MSRTC Bus station in Amravati

\section{CONCLUSION}

The survey analysis study shows application of QFD technique in the MSRTC transport system. QFD method ascertained to be a suitable and appropriate 
tool in the analysis of importance of quality of service features for users of public passenger transport system in Amravati district.

The following conclusions can be drawn from the conducted survey and after the implementation of QFD to the MSRTC services.

1. The study showed that drivers and Conductors are professionally much trained in handling passengers.

2. Almost all of the bus stations are lacking in the canteen facility.

3. The study reveals that there is still scope to increase the satisfaction level of passengers in MSRTC in the Amravati region. In general, the quality of services in the bus stations, the contemporary knowledge and skill of drivers and Conductors the ethics of service providers need to be improved by some extent.

Almost all of the respondents in each category worry about the quality issues at public transport sectors. Therefore, limited service in quality dimensions lead to customers" dissatisfaction at transport sector.

Notably $76 \%$ customers were agreed to recommend the MSRTC service to the travelers over the competing options. Based on the service features analysis within the house of quality, it was defined that the biggest influence is generated through system functioning parameters (reliability): ticket price with relative importance $13 \%$; user information with relative importance 9.7\%; frequency with relative importance $9.1 \%$. Cleanliness with relative importance $8.3 \%$, vehicle interior with $7.4 \%$ and age relaxation with $6.0 \%$; staff behaviour with relative importance $5.1 \%$; headway with relative importance $3 \%$; vehicle repairing with relative importance $1.2 \%$ --finally, based on the absolute importance, the order of elements that should be improved to reach the maximum effects and increase the users" satisfaction level is: ticket price - rank 1, user information - rank 2, frequency - rank 3, cleanliness- rank 4, vehicle interior - rank 5, age relaxation - rank 6, staff behavior - rank 7, headway- rank 8, vehicle repairing - rank 9.

\section{REFERENCES}

[1]. Dr. Arvind Chaudhari "A Study of facilities provided by Maharashtra State Road Transportation Corporation at Bus station to passengers in Maharashtra" vol.3 issue 4. April 2015- 43

[2]. Dr. Prakash Vishnu Pise "Study of Quality Services provided by MSRTC with special reference to Pune division” Bulletin Monumental,vol 21 issue 7 2020, http: //bulletinmonumental.com/.

[3]. Madhuri Rahatgaonkar, Mayura Mathankar "A study of passenger satisfaction in Maharashtra State Road Transportation Corporation in Amravati District" IJETR, Vol 6 Issue 4 Dec 2014.

[4]. Miss. Naziya Maldar "Maharashtra State Road Transportation Corporation (MSRTC, India): A study of issues and challenges" UGC Care Journal, Vol: 44, NO. 01( XX), Jan.-March (2021)

[5]. Dr.Urmila Vikas Patil " Analytical Study on Problems of Maharashtra State Road Transportation Corporation" JETIR, Volume 5 Issue 5 ,May 2018.

[6]. Kurtulmuşoğlu FB, Pakdil F, Atalay KD. Quality improvement strategies of highway bus service based on a fuzzy quality function deployment approach. Transp A Transp Sci 2016;12:175-202

[7]. Filipović S, Tica S, Živanović P, Milovanović B. Comparative analysis of the basic features of the expected and perceived quality of mass passenger public transport service in Belgrade. Transport 2009; 24:265-73.

[8]. Rao KCA, Thakar G, It M. Enhancement of Customer Satisfaction by QFD in Bus Service 2013:202-5

\section{Cite this article as:}

Prof. Sunil R. Kewate, Prof. Vivek R. Gandhewar, Miss. Vaishnavi R. Holey, "Survey Analysis for Quality Enhancement of MSRTC Bus Station - A Review Research", International Journal of Scientific Research in Science and Technology (IJSRST), Online ISSN: 2395-602X, Print ISSN: 2395-6011, Volume 8 Issue 5, pp. 362-369, SeptemberOctober 2021.

Available at

doi: https://doi.org/10.32628/IJSRST218548

Journal URL: https://ijsrst.com/IJSRST218548 